\title{
KEMAMPUAN KOMUNIKASI MATEMATIS SISWA DITINJAU DARI GAYA BELAJAR
}

\author{
Irma D. Wijayanti ${ }^{1}$, Rachmaniah M. Hariastuti ${ }^{2}$, Feby I. Yusuf ${ }^{3}$ \\ Universitas PGRI Banyuwangi $1^{1,2,3}$ \\ irmacunyil@gmail.com ${ }^{1}$
}

\begin{abstract}
ABSTRAK
Penelitian ini menggunakan metode kualitatif yang bertujuan untuk mengetahui kemampuan komunikasi matematis siswa ditinjau dari gaya belajar visual, auditorial, kinestetik pada materi aturan sinus dan cosinus. Penentuan responden dilakukan dengan metode purposive sampling dan snowball sampling. Dari setiap gaya belajar tersebut ditentukan masing-masing 3 subyek yang komunikatif untuk dilakukan wawancara sebagai proses triangulasi. Pengumpulan data dilakukan dengan metode tes dan wawancara. Data dianalisis secara kualitatif. Hasil penelitian menunjukkan : (1) siswa dengan gaya belajar visual dapat secara singkat menghubungkan benda nyata dan gambar ke dalam ide matematika, serta melakukan penarikan kesimpulan dari pernyataan matematika; (2) siswa dengan gaya belajar auditorial dapat mengubah kalimat menjadi ide matematika, menjelaskan ide-ide matematika (rumus), mengubah gambar peristiwa sehari-hari ke dalam simbol matematika, menjelaskan proses penyelesaian soal, serta dapat melakukan penarikan kesimpulan; (3) siswa dengan gaya belajar kinestetik dapat mengubah kalimat menjadi ide matematika, menjelaskan ide matematika dalam bentuk gambar dan rumus, serta mengubah gambar peristiwa sehari-hari ke dalam simbol matematika.
\end{abstract}

Kata kunci : komunikasi matematis, gaya belajar

\begin{abstract}
This study uses qualitative methods that aim to determine students' mathematical communication skills in terms of visual, auditory, kinesthetic learning styles on the material sine and cosine rules. Determination of respondents is done by purposive sampling and snowball sampling methods. Each of these learning styles is determined by each of 3 communicative subjects for interviews as a triangulation process. Data collection is done by the method of tests and interviews. Data were analyzed qualitatively. The results showed: (1) students with visual learning styles can briefly connect real objects and images into mathematical ideas, as well as draw conclusions from mathematical statements; (2) students with an auditory learning style can convert sentences into mathematical ideas, explain mathematical ideas (formulas), change images of everyday events into mathematical symbols, explain the process of problem solving, and can make conclusions; (3) students with kinesthetic learning styles can convert sentences into mathematical ideas, explain mathematical ideas in the form of pictures and formulas, and transform images of everyday events into mathematical symbols.
\end{abstract}

Keywords : mathematical communication, learning style 


\section{PENDAHULUAN}

NCTM (2000) menyatakan bahwa dalam pelaksanaan pembelajaran matematika di sekolah, siswa harus memperhatikan lima standar kompetensi yang utama yaitu kemampuan pemecahan masalah, kemampuan komunikasi, kemampuan koneksi, kemampuan penalaran, dan kemampuan representasi. Kelima standar tersebut tidak dapat muncul secara tiba-tiba tetapi harus melalui proses pembelajaran dan pembiasaan. Kemampuan pemecahan masalah merupakan kemampuan tertinggi yang membutuhkan dukungan dari empat kemampuan yang lain. Sedangkan kemampuan komunikasi merupakan kemampuan yang memiliki peran penting untuk dapat memahami empat kemampuan yang lain.

Secara umum kemampuan komunikasi matematis dikenal sebagai kemampuan siswa dalam menyampaikan ide matematika baik secara lisan maupun tulisan (Hodiyanto, 2017). Utomo, dkk (2015) menyatakan pendapat yang serupa, yaitu kemampuan komunikasi merupakan suatu aktivitas penyampaian informasi (pesan, ide, gagasan) dari satu pihak kepada pihak lain. Rohmah dan Khabibah (2014) berpendapat bahwa komunikasi matematis merupakan proses yang esensial dalam pembelajaran matematika karena melalui komunikasi, siswa merenungkan, memperjelas dan memperluas ide dan pemahaman mereka tentang hubungan dan argumen matematika. Kedua pendapat tersebut menunjukkan bahwa kemampuan komunikasi matematis merupakan suatu proses penting yang harus dikuasai oleh siswa dalam pembelajaran matematika. Siswa dengan kemampuan komunikasi matematis kurang berarti tidak dapat menerima dan menyampaikan informasi dalam pembelajaran matematika. Komunikasi matematis diperlukan agar siswa dapat memperluas pemahaman tentang matematika.

Kemampuan komunikasi matematis perlu dikembangkan karena matematika memuat bahasa-bahasa simbol dalam penyampaian ide atau gagasan matematika. Sumarmo (2012) menyatakan bahwa kemampuan komunikasi matematis meliputi kemampuan: (1) menyatakan situasi, gambar, diagram, atau benda nyata ke dalam bahasa, simbol, ide, atau model matematik; (2) menjelaskan ide, situasi, dan relasi matematika secara lisan atau tulisan; (3) mendengarkan, berdiskusi, dan menulis tentang matematika; (4) membaca dengan pemahaman suatu representasi matematika tertulis; serta (5) mengungkapkan kembali suatu uraian atau paragraf matematika dalam bahasa sendiri. Kelima komponen tersebut dapat menjadi indikator acuan untuk mengetahui kemampuan komunikasi matematis seseorang.

Lestari dan Yudhanegara (2017) menyatakan indikator acuan untuk mengetahui kemampuan komunikasi matematis seseorang dapat diketahui ketika siswa dapat: (1) menghubungkan benda nyata, gambar, dan diagram ke dalam ide matematika; (2) menjelaskan ide, situasi, dan relasi matematika secara lisan atau tulisan, dengan benda nyata, gambar, grafik, dan aljabar; (3) menyatakan peristiwa sehari-hari dalam bahasa matematika; (4) mendengarkan, diskusi, dan menulis tentang matematika; (5) membaca dengan pemahaman suatu presentasi matematika tertulis; (6) menyusun pertanyaan matematika yang relevan dengan situasi masalah; (7) membuat konjektur, menyusun argumen, merumuskan definisi dan generalisasi. Sedangkan menurut Taufiq (2014) indikator kemampuan komunikasi matematis meliputi: (1) merefleksikan benda-benda nyata, gambar, dan diagram ke dalam ide matematika; (2) membuat model situasi atau persoalan menggunakan metode lisan, tertulis, konkrit, grafik, dan aljabar; (3) menyatakan peristiwa sehari-hari dalam bahasa atau simbol matematika; (4) mendengarkan, berdiskusi, dan menulis tentang 
matematika; (5) membaca dengan pemahaman suatu presentasi matematika tertulis; (6) membuat konjektur, menyusun argumen, merumuskan definisi, dan generalisasi; (7) menjelaskan dan membuat pertanyaan tentang matematika.

Komunikasi matematis dapat dikaji melalui cara siswa dalam menerima suatu informasi pembelajaran. Cara seseorang menerima informasi dikenal sebagai gaya belajar. Gaya belajar merupakan cara yang dilakukan oleh individu untuk belajar dalam menerima suatu informasi. Gaya belajar menurut Lucy (2017) dibagi menjadi 3 jenis gaya, yaitu gaya belajar visual, auditorial, dan kinestetik. Prinansa (2017 : 5658) menyatakan bahwa siswa yang memiliki gaya belajar visual cenderung belajar dengan menitikberatkan ketajaman penglihatan, siswa yang memiliki gaya belajar auditorial cenderung belajar dengan mengandalkan pendengaran, sedangkan siswa yang memiliki gaya belajar kinestetik cenderung belajar dengan cara praktik langsung. Kemampuan siswa dalam mengkomunikasikan ide-ide matematisnya akan berkaitan dengan cara atau gaya siswa dalam menyerap, mengolah dan mengatur informasi yang diperolehnya pada saat pembelajaran. Dengan demikian, dapat dikatakan bahwa perbedaan gaya belajar siswa dapat memberikan pengaruh pada kemampuan komunikasi matematisnya.

Penelitian tentang hubungan antara gaya belajar dan kemampuan komunikasi matematis telah dilakukan sebelumnya. Penelitian yang dilakukan Islamiati (2018) pada siswa kelas $\mathrm{X}$ MAN 1 Kota Malang menunjukkan hasil kemampuan komunikasi tulis dan lisan tertinggi diperoleh siswa dengan gaya belajar kinestetik, diikuti oleh siswa dengan gaya belajar visual dan auditori. Penelitian lain yang dilakukan Auliana, dkk. (2017) di kelas VIIIA SMP Negeri VII Kediri menunjukkan hasil: (1) siswa dengan gaya belajar visual cenderung menjawab pertanyaan dengan singkat secara tulis maupun lisan melalui jawaban singkat yang hanya mengarah pada poin-poinnya saja; (2) siswa dengan gaya belajar auditorial cenderung mengkomunikasikan jawaban dengan kalimat yang panjang dan rinci menggunakan bahasanya sendiri tetapi tidak sesuai dengan maksud soal; sedangkan (3) siswa dengan gaya belajar kinestetik cenderung tidak menuliskan simbol-simbol matematika dalam mengkomunikasikan jawabannya.

Penelitian yang dilakukan oleh Syarifah, dkk (2017) di SMA Batik 1 Surakarta menunjukkan bahwa siswa dengan gaya belajar visual mempunyai kemampuan komunikasi matematis tertulis pada level 4 (sangat baik), siswa dengan gaya belajar auditorial mempunyai kemampuan komunikasi matematis tertulis pada level 2 (sedang), dan siswa dengan gaya belajar kinestetik mempunyai kemampuan komunikasi matematis tertulis pada level 2 (sedang). Penelitian lain yang dilakukan oleh Danaryanti dan Noviani (2015) di SMP Negeri 19 Banjarmasin menunjukkan bahwa rata-rata skor kemampuan komunikasi matematis siswa bergaya belajar visual lebih tinggi dibandingkan siswa bergaya belajar auditorial maupun kinestetik. Beberapa hasil penelitian tersebut menunjukkan bahwa gaya belajar siswa memiliki pengaruh terhadap kemampuan komunikasi matematis siswa.

Pembahasan di atas menjadi dasar pengkajian kemampuan komunikasi matematis pada siswa kelas XI di MAN 2 Banyuwangi, khususnya pada materi aturan sinus dan cosinus. Sehingga, penelitian ini bertujuan untuk mengetahui kemampuan komunikasi matematis siswa kelas XI IPA 5 MAN 2 Banyuwangi ditinjau dari gaya belajar visual, auditorial, kinestetik pada materi aturan sinus dan cosinus.

Sedangkan kemampuan komunikasi matematis dalam penelitian ini mengacu pada beberapa definisi di atas yang dapat diketahui melalui indikator sebagai berikut: 
(1) menghubungkan benda nyata, gambar, dan diagram ke dalam ide matematika; (2) menjelaskan ide, situasi, dan relasi matematika secara lisan atau tulisan, dengan benda nyata, gambar, dan aljabar; (3) menyatakan peristiwa sehari-hari dalam bahasa atau simbol matematika; dan (4) menarik kesimpulan dari pernyataan matematika.

\section{METODE}

Penelitian dilakukan dengan metode kualitatif deskriptif. Peneliti merupakan instrumen utama, sedangkan instrumen tambahan berupa tes dan pedoman wawancara. Triangulasi yang digunakan adalah triangulasi metode. Pengumpulan data diperoleh dari tes dan wawancara. Sedangkan analisis data dilakukan secara kualitatif.

Penelitian ini dilaksanakan pada bulan Juli 2019 pada siswa kelas XI IPA 5 MAN 2 Banyuwangi. Penelitian diawali dengan penentuan subyek berdasarkan gaya belajarnya. Dari masing-masing kelompok gaya belajar dipilih 3 orang yang komunikatif, kemudian diberikan tes materi aturan sinus dan cosinus. Setelah itu dilakukan wawancara kepada subyek yang berfungsi sebagai triangulasi data. Hasil triangulasi digunakan sebagai bahan analisis data. Langkah-langkah pelaksanaan penelitian dapat digambarkan dalam skema berikut.

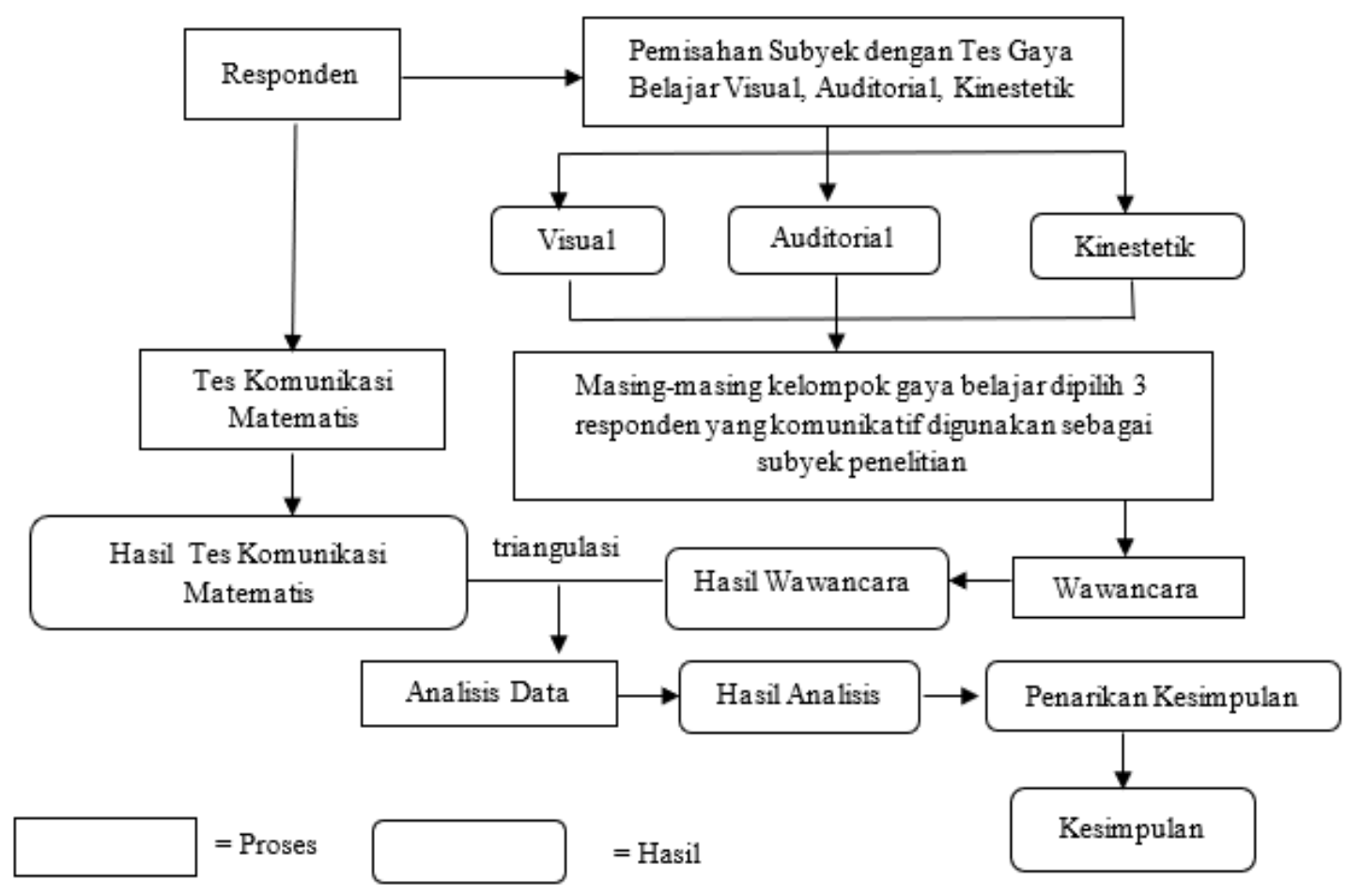

Gambar 1. Langkah-langkah penelitian 
Adapun indikator penentuan kemampuan komunikasi matematis subyek penelitian dapat ditentukan sebagai berikut.

Tabel 1. Indikator kemampuan komunikasi matematis siswa dalam materi aturan sinus dan cosinus

\begin{tabular}{|c|c|c|}
\hline & $\begin{array}{l}\text { Indikator kemampuan komunikasi } \\
\text { matematis }\end{array}$ & Indikator khusus \\
\hline $\bar{A}$ & $\begin{array}{l}\text { Menghubungkan benda nyata dan } \\
\text { gambar kedalam ide matematika; }\end{array}$ & $\begin{array}{l}\text { Siswa dapat menghubungkan } \\
\text { gambar ke dalam ide matematika. }\end{array}$ \\
\hline B & $\begin{array}{l}\text { Menjelaskan ide, situasi, dan relasi } \\
\text { matematika secara lisan atau tulisan } \\
\text { dengan benda nyata, gambar, dan } \\
\text { aljabar; }\end{array}$ & $\begin{array}{l}\text { 1. Siswa dapat menjelaskan ide-ide } \\
\text { matematika dalam suatu gambar. } \\
\text { 2. Siswa dapat menjelaskan ide-ide } \\
\text { matematika dalam rumus. } \\
\text { 3. Siswa dapat menjelaskan proses } \\
\text { penyelesaian soal. }\end{array}$ \\
\hline $\mathrm{C}$ & $\begin{array}{l}\text { Menyatakan peristiwa sehari-hari } \\
\text { dalam bahasa atau simbol } \\
\text { matematika; }\end{array}$ & $\begin{array}{l}\text { 1. Siswa dapat mengubah gambar } \\
\text { peristiwa sehari-hari ke dalam } \\
\text { bentuk simbol matematika. }\end{array}$ \\
\hline $\mathrm{D}$ & $\begin{array}{l}\text { Menarik kesimpulan dari pernyataan } \\
\text { matematika. }\end{array}$ & $\begin{array}{l}\text { 1. Siswa dapat menarik kesimpulan } \\
\text { sesuai dengan soal yang diberikan. }\end{array}$ \\
\hline
\end{tabular}

\section{HASIL DAN PEMBAHASAN}

Penelitian ini dilakukan di kelas XI IPA 5 MAN 2 Banyuwangi pada bulan Juli 2019. Dari 36 responden, diperoleh 10 responden memiliki gaya belajar visual, 16 responden memiliki gaya belajar auditorial, dan 3 responden memiliki gaya belajar kinestetik. Sedangkan 3 responden terdeteksi memiliki gaya belajar auditorialkinestetik dan 4 responden terdeteksi memiliki gaya belajar visual-auditorial. Selanjutnya dari tiap gaya belajar yang diperoleh ditentukan masing-masing 3 subyek yang komunikatif untuk dilakukan wawancara sebagai proses triangulasi.

Hasil triangulasi data pada subyek visual ditunjukkan pada tabel 2 berikut.

Tabel 2. Triangulasi dan analisis data subyek visual

\begin{tabular}{|c|c|c|c|}
\hline $\begin{array}{l}\text { Indi } \\
\text { kator }\end{array}$ & Hasil tes & Wawancara & Kesimpulan \\
\hline A1 & $\begin{array}{l}\text { Subyek dapat menunjukkan } \\
\text { melalui tulisan bahwa } \\
\text { gambar dalam soal dapat } \\
\text { diubah menjadi ide } \\
\text { matematika bentuk segitiga. }\end{array}$ & $\begin{array}{l}\text { Subyek dapat menunjukkan } \\
\text { melalui lisan dan tulisan } \\
\text { bahwa gambar dalam soal } \\
\text { dapat diubah menjadi ide } \\
\text { matematika bentuk segitiga. }\end{array}$ & $\begin{array}{l}\text { Subyek dapat mengubah } \\
\text { kalimat menjadi ide } \\
\text { matematika dalam bentuk } \\
\text { lisan dan tulisan }\end{array}$ \\
\hline B1 & $\begin{array}{l}\text { Subyek dapat menjelaskan } \\
\text { ide-ide matematika dalam } \\
\text { gambar segitiga secara } \\
\text { tertulis }\end{array}$ & $\begin{array}{l}\text { Subyek dapat menjelaskan } \\
\text { ide-ide matematika dalam } \\
\text { gambar segitiga secara lisan } \\
\text { dan tulis }\end{array}$ & $\begin{array}{lr}\begin{array}{l}\text { Subyek } \\
\text { menjelaskan }\end{array} & \text { dapat } \\
\text { matematika } & \text { (gambar) } \\
\text { dalam bentuk } & \text { lisan dan } \\
\text { tulisan } & \end{array}$ \\
\hline B2 & $\begin{array}{l}\text { Subyek dapat menuliskan } \\
\text { aturan sinus dengan tepat, } \\
\text { tetapi belum dapat } \\
\text { menuliskan rumus aturan }\end{array}$ & $\begin{array}{l}\text { Subyek dapat menyebut } \\
\text { dan menuliskan aturan } \\
\text { sinus dengan tepat, tetapi } \\
\text { belum dapat menyebut dan }\end{array}$ & $\begin{array}{lr}\text { Subyek belum } & \text { dapat } \\
\text { maksimal } & \text { dalam } \\
\text { menjelaskan } & \text { ide-ide } \\
\text { matematika } & \text { (rumus) }\end{array}$ \\
\hline
\end{tabular}




\begin{tabular}{|c|c|c|c|}
\hline & $\begin{array}{l}\text { cosinus yang diminta } \\
\text { dengan tepat }\end{array}$ & $\begin{array}{l}\text { menuliskan aturan cosinus } \\
\text { dengan tepat }\end{array}$ & bentuk lisan dan tulisan \\
\hline B3 & $\begin{array}{l}\text { Subyek dapat menjelaskan } \\
\text { proses penyelesaian soal } \\
\text { tentang aturan sinus dan } \\
\text { aturan cosinus sesuai } \\
\text { dengan rumus dari awal } \\
\text { hingga jawaban akhir } \\
\text { secara tertulis }\end{array}$ & $\begin{array}{l}\text { Secara lisan dan tulis, } \\
\text { subyek dapat menjelaskan } \\
\text { proses penyelesaian soal } \\
\text { tentang aturan sinus sesuai } \\
\text { dengan rumus dari awal } \\
\text { hingga jawaban akhir, } \\
\text { tetapi pada penyelesaian } \\
\text { aturan sinus dihasilkan } \\
\text { jawaban yang kurang tepat }\end{array}$ & 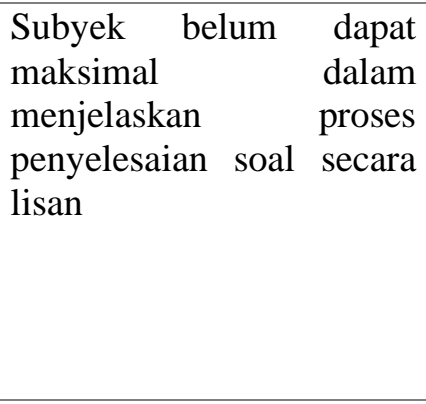 \\
\hline $\mathrm{C} 1$ & $\begin{array}{l}\text { Secara tertulis, subyek } \\
\text { hanya dapat mengubah satu } \\
\text { dari dua representasi soal } \\
\text { ke dalam simbol } \\
\text { matematika }\end{array}$ & $\begin{array}{l}\text { Secara lisan dan tulis, } \\
\text { subyek hanya dapat } \\
\text { mengubah satu dari dua } \\
\text { representasi soal ke dalam } \\
\text { simbol matematika }\end{array}$ & 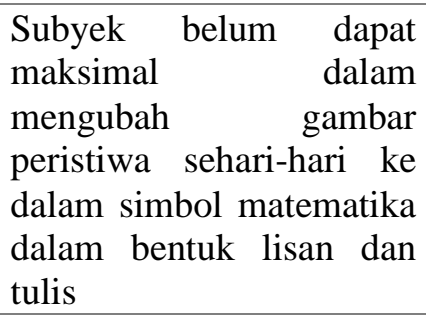 \\
\hline D1 & $\begin{array}{l}\text { Secara tertulis, subyek } \\
\text { hanya dapat melakukan } \\
\text { satu dari dua penarikan } \\
\text { kesimpulan yang diminta }\end{array}$ & $\begin{array}{l}\text { Secara lisan dan tulis, } \\
\text { subyek dapat melakukan } \\
\text { penarikan kesimpulan }\end{array}$ & $\begin{array}{l}\text { Subyek dapat melakukan } \\
\text { penarikan kesimpulan } \\
\text { secara lisan dan tertulis }\end{array}$ \\
\hline
\end{tabular}

Hasil triangulasi menunjukkan bahwa subyek gaya belajar visual dapat secara singkat menghubungkan benda nyata dan gambar ke dalam ide matematika, serta melakukan penarikan kesimpulan dari pernyataan matematika. Tetapi subyek belum dapat maksimal dalam menjelaskan ide, situasi, dan relasi matematika secara lisan atau tulisan dengan benda nyata, gambar, dan aljabar, serta belum dapat maksimal dalam menyatakan peristiwa sehari-hari dalam bahasa atau simbol matematika. Hal ini bersesuaian dengan penelitian Auliana, dkk (2017) bahwa siswa yang bergaya belajar visual cenderung mengkomunikasikan soal dengan jawaban yang singkat melalui proses menjawab soal dengan jawaban yang menuju ke poin-poinnya saja.

Hasil triangulasi data pada subyek auditorial ditunjukkan pada tabel 3 berikut.

Tabel 3. Triangulasi dan analisis data subyek auditorial

\begin{tabular}{|c|c|c|c|}
\hline $\begin{array}{l}\text { Indi } \\
\text { kator }\end{array}$ & Hasil tes & Wawancara & Kesimpulan \\
\hline A1 & $\begin{array}{l}\text { Secara tertulis subyek dapat } \\
\text { menunjukkan bahwa gambar } \\
\text { dalam soal dapat diubah } \\
\text { menjadi ide matematika } \\
\text { bentuk segitiga. }\end{array}$ & $\begin{array}{l}\text { Secara lisan dan tertulis, } \\
\text { subyek dapat menunjukkan } \\
\text { bahwa gambar dalam soal } \\
\text { dapat diubah menjadi ide } \\
\text { matematika bentuk segitiga. }\end{array}$ & $\begin{array}{l}\text { Subyek dapat mengubah } \\
\text { kalimat menjadi ide } \\
\text { matematika dalam bentuk } \\
\text { lisan dan tulisan }\end{array}$ \\
\hline B1 & $\begin{array}{l}\text { Secara tertulis, subyek belum } \\
\text { dapat menjelaskan ide-ide } \\
\text { matematika pada gambar } \\
\text { segitiga }\end{array}$ & $\begin{array}{lr}\text { Secara lisan dan tulisan, } \\
\text { subyek belum } & \text { dapat } \\
\text { menjelaskan } & \text { ide-ide } \\
\text { matematika pada gambar } \\
\text { segitiga }\end{array}$ & $\begin{array}{l}\text { Subyek belum dapat } \\
\text { menjelaskan ide-ide } \\
\text { matematika } \\
\text { dalam bentuk lisan dan } \\
\text { tulisan }\end{array}$ \\
\hline B2 & $\begin{array}{l}\text { Subyek dapat menjelaskan } \\
\text { ide-ide matematika pada } \\
\text { rumus aturan sinus dan }\end{array}$ & $\begin{array}{l}\text { Secara lisan dan tulisan, } \\
\text { subyek dapat menjelaskan } \\
\text { ide-ide matematika pada }\end{array}$ & $\begin{array}{l}\text { Subyek } \\
\text { menjelaskan } \\
\text { matematika }\end{array}$ \\
\hline
\end{tabular}




\begin{tabular}{|c|c|c|c|}
\hline & $\begin{array}{l}\text { aturan cosinus dalam bentuk } \\
\text { tulisan }\end{array}$ & $\begin{array}{l}\text { rumus aturan sinus dan } \\
\text { aturan cosinus }\end{array}$ & $\begin{array}{l}\text { dalam bentuk lisan dan } \\
\text { tulisan }\end{array}$ \\
\hline B3 & $\begin{array}{l}\text { Subyek dapat menjelaskan } \\
\text { proses penyelesaian soal } \\
\text { tentang aturan sinus dan } \\
\text { aturan cosinus sesuai dengan } \\
\text { rumus dari awal hingga } \\
\text { jawaban akhir secara tertulis, } \\
\text { tetapi pada penyelesaian soal } \\
\text { tentang aturan cosinus } \\
\text { jawaban yang diberikan } \\
\text { kurang benar }\end{array}$ & $\begin{array}{l}\text { Subyek dapat menjelaskan } \\
\text { proses penyelesaian soal } \\
\text { tentang aturan sinus dan } \\
\text { aturan cosinus secara lisan } \\
\text { dan tulisan }\end{array}$ & $\begin{array}{lr}\text { Subyek } & \text { dapat } \\
\text { menjelaskan } & \text { proses } \\
\text { penyelesaian soal } & \text { secara } \\
\text { lisan dan tulisan } & \end{array}$ \\
\hline $\mathrm{C} 1$ & $\begin{array}{l}\text { Secara tertulis, subyek dapat } \\
\text { mengubah satu dari dua } \\
\text { representasi soal ke dalam } \\
\text { simbol matematika }\end{array}$ & $\begin{array}{l}\text { Secara lisan dan tulis, } \\
\text { subyek dapat mengubah } \\
\text { representasi soal ke dalam } \\
\text { simbol matematika }\end{array}$ & $\begin{array}{l}\text { Subyek dapat mengubah } \\
\text { gambar peristiwa sehari- } \\
\text { hari ke dalam simbol } \\
\text { matematika dalam bentuk } \\
\text { lisan dan tulis }\end{array}$ \\
\hline D1 & $\begin{array}{l}\text { Secara tertulis, subyek hanya } \\
\text { dapat melakukan satu dari } \\
\text { dua penarikan kesimpulan } \\
\text { yang diminta }\end{array}$ & $\begin{array}{l}\text { Secara lisan dan tulis, } \\
\text { subyek dapat melakukan } \\
\text { penarikan kesimpulan }\end{array}$ & $\begin{array}{l}\text { Subyek dapat melakukan } \\
\text { penarikan kesimpulan } \\
\text { secara lisan dan tertulis }\end{array}$ \\
\hline
\end{tabular}

Hasil triangulasi pada subyek dengan gaya belajar auditorial menunjukkan bahwa subyek dapat mengubah kalimat menjadi ide matematika; dapat menjelaskan ide-ide matematika (rumus); mengubah gambar peristiwa sehari-hari ke dalam simbol matematika; menjelaskan proses penyelesaian soal; serta dapat melakukan penarikan kesimpulan, tetapi belum dapat menjelaskan ide-ide matematika dalam bentuk gambar. Hal ini berbeda dengan penelitian Syarifah, dkk (2017) yang memberikan hasil siswa dengan gaya belajar auditorial cenderung kurang mampu dalam merepresentasikan ide-ide matematis ke dalam model matematika atau tulisan, menggambarkan ide-ide matematis secara visual, dan kurang mampu menggunakan lambang, notasi, dan persamaan matematika secara lengkap dan benar.

Hasil triangulasi data pada subyek kinestetik ditunjukkan pada tabel 4 berikut.

Tabel 4. Triangulasi dan analisis data subyek kinestetik

\begin{tabular}{|c|c|c|c|}
\hline Indi & Hasil tes & Wawancara & Kesimpulan \\
\hline A1 & $\begin{array}{l}\text { Subyek dapat menunjukkan } \\
\text { bahwa gambar dalam soal } \\
\text { dapat diubah menjadi ide } \\
\text { matematika bentuk segitiga } \\
\text { secara tertulis }\end{array}$ & $\begin{array}{l}\text { Subyek dapat menunjukkan } \\
\text { bahwa gambar dalam soal } \\
\text { dapat diubah menjadi ide } \\
\text { matematika bentuk segitiga } \\
\text { secara lisan dan tertulis }\end{array}$ & $\begin{array}{l}\text { Subyek dapat mengubah } \\
\text { kalimat menjadi ide } \\
\text { matematika dalam bentuk } \\
\text { lisan dan tulisan }\end{array}$ \\
\hline B1 & $\begin{array}{l}\text { Subyek belum dapat } \\
\text { menjelaskan ide-ide } \\
\text { matematika pada gambar } \\
\text { segitiga secara tertulis }\end{array}$ & $\begin{array}{l}\text { Subyek dapat menjelaskan } \\
\text { ide-ide matematika pada } \\
\text { gambar segitiga dalam } \\
\text { bentuk lisan dan tulisan }\end{array}$ & $\begin{array}{lr}\begin{array}{l}\text { Subyek } \\
\text { menjelaskan }\end{array} & \text { dapat } \\
\text { matematika } & \text { (gambar) } \\
\text { dalam bentuk } & \text { lisan dan } \\
\text { tulisan } & \end{array}$ \\
\hline B2 & $\begin{array}{lr}\text { Subyek tidak } & \text { dapat } \\
\text { menjelaskan } & \text { ide-ide } \\
\text { matematika pada } & \text { rumus }\end{array}$ & $\begin{array}{l}\text { Subyek dapat menjelaskan } \\
\text { ide-ide matematika pada } \\
\text { rumus aturan sinus dan }\end{array}$ & $\begin{array}{l}\text { Subyek } \\
\text { menjelaskan } \\
\text { matematika }\end{array}$ \\
\hline
\end{tabular}




\begin{tabular}{|c|c|c|c|}
\hline & $\begin{array}{l}\text { aturan sinus dan aturan } \\
\text { cosinus dalam bentuk tulisan }\end{array}$ & $\begin{array}{l}\text { aturan cosinus dalam } \\
\text { bentuk lisan dan tulisan }\end{array}$ & $\begin{array}{l}\text { dalam bentuk lisan } \\
\text { tulisan }\end{array}$ \\
\hline B3 & $\begin{array}{l}\text { Subyek tidak dapat } \\
\text { menjelaskan } \\
\text { penyelesaian soal tentang } \\
\text { aturan sinus dan aturan } \\
\text { cosinus sesuai dengan rumus } \\
\text { dari awal hingga jawaban } \\
\text { akhir secara tertulis }\end{array}$ & $\begin{array}{l}\text { Subyek dapat menjelaskan } \\
\text { proses penyelesaian soal } \\
\text { tentang aturan sinus dan } \\
\text { aturan cosinus secara lisan } \\
\text { dan tertulis, tetapi belum } \\
\text { dapat memberikan jawaban } \\
\text { yang benar pada soal } \\
\text { tentang aturan cosinus }\end{array}$ & $\begin{array}{ll}\text { Subyek belum } & \text { dapat } \\
\text { maksimal } & \text { dalam } \\
\text { menjelaskan } & \text { proses } \\
\text { penyelesaian soal } & \text { secara } \\
\text { lisan dan tertulis } & \end{array}$ \\
\hline C1 & $\begin{array}{l}\text { Secara tertulis, subyek } \\
\text { belum dapat mengubah satu } \\
\text { dari dua representasi soal ke } \\
\text { dalam simbol matematika }\end{array}$ & $\begin{array}{l}\text { Secara lisan dan tertulis, } \\
\text { subyek dapat mengubah } \\
\text { representasi soal ke dalam } \\
\text { simbol matematika }\end{array}$ & $\begin{array}{l}\text { Subyek dapat mengubah } \\
\text { gambar peristiwa sehari- } \\
\text { hari ke dalam simbol } \\
\text { matematika dalam bentuk } \\
\text { lisan dan tulis }\end{array}$ \\
\hline D1 & $\begin{array}{l}\text { Secara tertulis, subyek } \\
\text { belum dapat melakukan } \\
\text { penarikan kesimpulan yang } \\
\text { diminta }\end{array}$ & $\begin{array}{l}\text { Subyek hanya dapat } \\
\text { melakukan } \\
\text { kesimpulan yang diminta } \\
\text { secara lisan }\end{array}$ & $\begin{array}{l}\text { Subyek hanya dapat } \\
\text { melakukan penarikan } \\
\text { kesimpulan secara lisan }\end{array}$ \\
\hline
\end{tabular}

Hasil triangulasi pada subyek dengan gaya belajar kinestetik menunjukkan bahwa subyek dapat mengubah kalimat menjadi ide matematika; menjelaskan ide matematika dalam bentuk gambar dan rumus; serta mengubah gambar peristiwa sehari-hari ke dalam simbol matematika, tetapi belum dapat menjelaskan proses penyelesaian soal dan melakukan penarikan kesimpulan. Hal ini bersesuaian dengan penelitian Auliana, dkk (2017) bahwa siswa dengan gaya belajar kinestetik cenderung tidak memperhatikan simbol-simbol matematika, tidak menuliskan simbol-simbol matematika dalam mengkomunikasikan jawabannya dan juga tidak membuat kesimpulan.

\section{SIMPULAN DAN SARAN}

Berdasarkan hasil penelitian kemampuan komunikasi matematis siswa ditinjau dari gaya belajar yang telah dilakukan, maka dapat disimpulkan bahwa (1) siswa dengan gaya belajar visual dapat secara singkat menghubungkan benda nyata dan gambar ke dalam ide matematika, serta melakukan penarikan kesimpulan dari pernyataan matematika; (2) siswa dengan gaya belajar auditorial dapat mengubah kalimat menjadi ide matematika; menjelaskan ide-ide matematika (rumus); mengubah gambar peristiwa sehari-hari ke dalam simbol matematika; menjelaskan proses penyelesaian soal; serta dapat melakukan penarikan kesimpulan; (3) siswa dengan gaya kinestetik dapat mengubah kalimat menjadi ide matematika; menjelaskan ide matematika dalam bentuk gambar dan rumus; serta mengubah gambar peristiwa sehari-hari ke dalam simbol matematika.

Berdasarkan kesimpulan yang telah diperoleh hendaknya siswa lebih sering dilatih mengerjakan soal-soal uraian dengan langkah penyelesaian yang runtut sebagai latihan penguatan kemampuan komunikasi matematis. Penelitian ini juga dapat dikembangkan untuk mengidentifikasi kemampuan komunikasi pada siswa dengan gaya belajar ganda. 


\section{DAFTAR PUSTAKA}

Auliana, N., Handayani, A. D., dan Katminingsih, Y. 2017. Analisis Kemampuan Komunikasi Matematis Siswa pada Materi Statistika Ditinjau dari Gaya Belajar Visual, Auditorial, Kinestetik (VAK). Simki-Techsain, Vol. 1(6) : 3-8.

Danaryanti, A., dan Noviani, H. 2015. Pengaruh Gaya Belajar Matematika Siswa Kelas VII Terhadap Kemampuan Komunikasi Matematis di SMP. EDU-MAT Jurnal Pendidikan Matematika, Vol. 3(2) : 204-212.

Hodiyanto. 2017. Kemampuan Komunikasi Matematis dalam Pembelajaran Matematika. AdMathEdu, Vol. 7(1) : 9-18.

Islamiati, N. 2018. Analisis Kemampuan Komunikasi Matematis Siswa dalam Memecahkan Masalah Ditinjau dari Gaya Belajar Melalui Model Pembelajaran Group Investigation dengan Peer Assessment. Tesis tidak dipublikasikan. Malang: Universitas Negeri Malang.

Lestari, K. E., dan Yudhanegara, M. R. 2017. Penelitian Pendidikan Matematika. Bandung: PT Refika Aditama.

Lucy, B. 2017. Tes Minat dan Bakat Anak. Jakarta: Penebar Plus (Penebar Swadaya Grup).

NCTM. 2000. Principle and Standards for School Mathematics. USA: NCTM.

Prinansa, D. J. 2017. Pengembangan Strategi \& Model Pembelajaran. Bandung: CV Pustaka Setia.

Rohmah, N., dan Khabibah, S. 2014. Profil Komunikasi Siswa dalam Pemecahan Masalah Matematika Ditinjau dari Gaya Kognitif dan Jenis Kelamin. Jurnal Ilmiah Pendidikan Matematika, Vol. 3(2) : 121-130.

Sumarmo, U. 2012. Pendidikan Karakter serta Pengembangan Berpikir dan Disposisi Matematik dalam Pembelajaran Matematika. Makalah pada Seminar Pendidikan Matematika, Nusa Tenggara Timur, 25 Februari 2012.

Syarifah, T. J., Sujatmiko, P., dan Setiawan, R. 2017. Analisis Kemampuan Komunikasi Matematis Tertulis Ditinjau dari Gaya Belajar pada Siswa Kelas XI MIPA 1 SMA Batik 1 Surakarta Tahun Pelajaran 2015/2016. Jurnal Pendidikan Matematika dan Matematika (JPMM) Solusi, Vol. I(2) : 1-19.

Taufiq. 2014. Meningkatkan Kemampuan Komunikasi dan Pemecahan Masalah serta Disposisi Matematik Siswa SMP Melalui Pendekatan Kontekstual dan Strategi Think-Talk-Write. Tesis tidak diterbitkan. Bandung: Universitas Pendidikan Indonesia.

Utomo, F. H., Wardhani, I. S., dan Asrori, M. A. 2015. Komunikasi Matematika Berdasarkan Teori Van Hiele pada Mata Kuliah Geometri Ditinjau dari Gaya Belajar Mahasiswa Program Studi Pendidikan Matematika. Cendekia, Vol. 9(2) : 159-170. 